\title{
Sciendo
}

Journal of Intercultural Management

Vol. 12 | No. 2 | June 2020 | pp. 106-133

DOI 10.2478/joim-2020-0040

\section{Jolanta Maj}

Opole University of Technology

Opole, Poland

j.maj@po.edu.pl

ORCID ID: 0000-0001-5542-0713

\section{Sabina Kubiciel-Lodzińska}

Opole University of Technology

Opole, Poland

s.kubiciel-lodzinska@po.edu.pl

ORCID ID: 0000-0002-5465-6967

\section{Katarzyna Widera}

Opole University of Technology

Opole, Poland

k.widera@po.edu.pl

ORCID ID: 0000-0003-0651-8049

\section{The Willingness to Employ Immigrants in Polish Organizations}




\section{ABSTRACT}

Objective: For a long time Poland has been perceived as a rather homogenous society. However, cultural diversity and differences started to become visible after 1989 and have gained on importance since then. Combined with an increasing shortage of native workforce, the question of immigrants' employment by Polish organisations becomes a burning issue. We have therefore decided to determine whether the fact of employing immigrants or the intention to do so in the foreseeable future affects the perception of foreign workers and the necessity of hiring them

Methodology: For this purpose, we conducted a survey among 263 entrepreneurs from the Opolskie Voivodship.

Findings: The study has demonstrated a very strong, statistically-relevant correlation between the willingness to employ immigrants and the attitude towards an employee's country of origin. Also correlations between other analysed variables have been found statistically relevant

Value Added: The paper is an introduction to a debate on the role of immigrants on the Polish labour-market as it presents the point-of view of employers and their willingness to employ immigrants.

Recommendations: It is recommended for decision-makers to facilitate access of a wider group of immigrants to the Polish labour market, especially since a significant group of employees recognises the upcoming issue of workforce shortages and the necessity to reach for foreign employees in order to stay competitive.

Key words: Cultural diversity, Labour immigration, Foreign workforce, Immigrants

JEL codes: M21, M54, O15

\section{Introduction}

For a long time Poland has been perceived as a rather homogenous society. However, cultural diversity and differences started to become visible after 1989 and have gained on importance after Poland joined the European Union, yet according to Włoch (2013), immigration and immigrants are not being perceived as important issues. Although surveys on attitudes point to a relatively positive attitude towards immigrants (CBOS, 2017) as suggested by Klaus and Wencel, most Poles rarely encounter cultural, racial, religious 
or national diversity in their everyday life (Klaus \& Wencel, 2010). However, this situation is about to change. Socio-demographic processes, such as population ageing, significantly influence the supply of native workforce (Arltova \& Langhamrova, 2010) and Poland is shifting from an emigration into an immigration country (Solga \& Kubiciel-Lodzinska, 2017).

The lack of native employees is becoming visible not only among blue collar jobs, i.e. the so-called secondary labour market, but also among white collar jobs, i.e. the primary labour market, which demand specialised qualifications and competencies. Therefore, not only external processes enforce a gradual workforce differentiation, but also new trends and strategies within human resources management, such as diversity management processes (Dvorakova \& Langhamrova, 2013). In some cases, organisations implementing diversity management deliberately hire foreign workforce in order to further diversify their labour and thus enjoy the benefits diversity management has to offer. The positive consequences of diversity include greater creativity, innovation and flexibility of the work teams. Diverse employees have a variety of points of view and broader information (Jehn et al., 1999; Lau \& Murnighan, 1998; Schweiger et al., 1986). Research (D'Souza \& Colarelli, 2010) shows that visible characteristics affect teamwork, especially when team members have prejudice against different groups (Dovidio et al., 2002).

In view of the increasing economic immigration and the inflow of foreign workforce, we have attempted to determine whether the fact of employing immigrants or the intention to do so in the foreseeable future determines the perception of foreign workers as well as the perceived necessity of hiring them. We understand the term "immigrant" as all people not born in Poland or not having Polish citizenship and the term "workers" as employees. For this purpose, we conducted surveys among entrepreneurs from the Opolskie Voivodship, which is referred to as migrational (Heffner \& Solga, 2013) - characterised by a long tradition of departures (usually foreign ones), with their accompanying social, demographic and economic consequences. The Opolskie Voivodship has become a kind of a 'laboratory' for the study of migration processes, in 
particular emigration. For several years now, it has also been the place of research related to the process of foreign immigration, mainly related to the labour market (Kubiciel-Lodzińska, 2017; Solga \& Kubiciel-Lodzinska, 2017) or to student mobility (Kubiciel-Lodzinska \& Ruszczak, 2016).

The paper is organised as follows. The first and second parts outline the recent developments in the Polish labour market in relation to the progressing differentiation of the workforce and the economic immigration, thus establishing the importance of the topic and the research problem. The third part outlines the research design and methodology. The fourth part presents the research results, followed by the final, fifth part, i.e. the conclusion and discussion section.

\section{Motivation for employing foreign workforce}

There can be a number of reasons to explain the demand for foreign workforce and the employers' motivation to employ immigrants. Among the reasons, researchers point to the mismatch between the supply of and demand for labour (Dietz \& Kaczmarczyk, 2008; Constant, 2014), labour market segmentation (Piore, 1979; Douglas et al., 2009) and, as result of socio-demographic changes (Van de Kaa, 1999), the services market by increasing the demand for elderly care services. Usually these factors occur in combination, therefore a significant area of migration research is the position of foreign workforce on the domestic labour market and the analysis of the competition between native and foreign workers (Peri, 2016; Foged \& Peri, 2016), but also the differences in employing native and foreign workforce in terms of organisational behaviour (Ang et al., 2003).

In terms of workforce supply and demand, researchers emphasise that immigrants are very often hired for works in which the natives are not interested (Hamid et al., 2011). They also pointed out the lower costs of foreign workforce (Hamid et al., 2011), which can create wage gaps between native and migrant employees (Gheasi et al., 2017). These findings however apply 
mostly only to low skilled workers who perform the so-called blue-collar jobs, identified with the secondary labour market segment (Doeringer \& Piore, 1985). However, very often high-skilled and qualified foreign workforce is employed for white-collar jobs, i.e. the primary labour market, where there are not enough native workers with specific specialised qualifications (Reyneri, 2004). The high skilled workers, who possess special skills and experience, improve an organisation's productivity (Jordaan, 2018). Another group of research analyses the importance of foreign workforce in the increase of workforce diversity and its impact on innovation, creation of new firms or trade (Parrotta et al., 2014; Ottaviano \& Peri, 2006; Hunt, 2011). Some studies also analysed a hypothesis stating that migrant workers have a special set of competencies, skills and experience, which can contribute to a company's performance (Markusen \& Trofimenko, 2009; Aleksynska \& Tritah, 2015), which in turn would be in accordance with the assumptions of diversity management (Mor Barak, 2010).

Despite the growing importance of labour immigration to Poland, research conducted among employers on the demand for immigrant work is rather limited. Moreover, studies in the field of integration, including economic integration, were conducted mainly among immigrants (Górny, 2007; Grzymała-Kazłowska, 2008; Bloch \& Gozdziak, 2010; Brzozowski \& Pędziwiatr, 2014). Gmaj (2005) conducted fifteen in-depth interviews with employers, which were aimed at identifying the reasons for picking immigrants. A study of the demand for immigrant work was also conducted by the Institute of Labour and Social Affairs (IPiSS) (Golinowska, 2004). According to the study, the main reason for employing immigrants was his or her specific qualifications, perceived as required for maintaining business on the market (this included managers and skilled workers with special and limited skills). Another reason was the desire to distinguish a company from its competition and win over customers (Chinese or Vietnamese chefs, foreign-language teachers). The third most mentioned reason was the immigrants' knowledge about their domestic market, which would enable the organisation to smoothly enter new 
areas (trade professionals who know the country's language and its customs and who already have established business contacts). These findings are in line with the findings presented by Jordaan (2018), Aleksynska \& Tritah (2015) and Markusen \& Trofimenko (2009). The demand for immigrant work was also one of the elements of another project conducted by the IPiSS. Respondents were asked, among other things, about the issue of employing immigrants in order to fill vacancies. Among the indicated reasons for hiring immigrants were lower wage expectations and a greater willingness to work, combined with the lack of willingness of Polish labour to work. Despite the low number of immigrants actually working in the analysed organisations, the firms' willingness to employ an immigrant was high (Kukulak-Dolata \& Sobocka-Szczapa, 2013). In addition, the Centre of Migration Research conducted research on the demand for foreign workforce among Polish organisations (Grabowska-Lusińska \& Żylicz, 2008). However, the results demonstrated a very low demand for foreign workforce, i.e. not exceeding 1 percent.

\section{From homogeneity to heterogeneity in Poland}

In order to understand the importance of the analysed issue, especially in the Polish context, it is necessary to underline that Poland is a relatively homogenous society and the current influx of economic immigrants can be treated as the first, more significant diversification of society since 1945. According to the last Census from 2011, 97\% people declared Polish nationality, 2.2\% declared Silesian nationality, 0.6\% - Kashubian nationality and 0.4 - German nationality (respondents were allowed to name more than one nationality). In regards to religion, $95.95 \%$ declared belonging to the Roman Catholic denomination, $0.44 \%$ - to the Orthodox Church and $0.39 \%$ to the Confession of Jehovah's Witnesses (GUS, 2014).

Due to the freedom of movement of workers within the European Union, the European Economic Area and Switzerland official statistics regarding the number of economic immigrants from those countries have to be treated 
with great caution. Furthermore, surveys on attitudes point to fairly positive attitudes towards citizens from West European countries. Also, due to the increasing number of East European and Asian immigrants, the issue of economic immigration from those regions is far more interesting.

As of 1 January 2018, the rules on immigrant employment were amended. In order to enter the Polish labour market, citizens of the so-called third countries must have a document allowing them to enter the Polish labour market, i.e. a work permit, seasonal work permit (new instrument introduced in 2018, therefore not yet present in the statistics), employer declaration on entrusting a job to an immigrant, or temporary residence and work permit. As presented in Table 1, a vast majority (81.72\%) of work permits issued in 2017 concerned Ukrainian citizens. The second biggest group for which work permits were issued were Belarusians.

Table 1. Number of work permits issued in 2017 by country of origin

\begin{tabular}{|l|l|l|}
\hline Country of origin & $\begin{array}{l}\text { Number of work permits } \\
\text { issued (absolute value) }\end{array}$ & Percentage \\
\hline Ukraine & 192,547 & 81.72 \\
\hline Belarus & 10,518 & 4.46 \\
\hline Nepal & 7,075 & 3.00 \\
\hline India & 3,938 & 1.67 \\
\hline Moldavia & 3,792 & 1.61 \\
\hline
\end{tabular}

Source: own research, based on data provided by the MPiPS (2017).

An even more unambiguous situation emerges when taking into consideration the number of issued employer declarations of entrusting a job to an immigrant, which is been presented in Table 2, where almost $94 \%$ of all declarations were issued to Ukrainians. 
Table 2. Number of issued employer declarations of entrusting a job to an immigrant in 2017 by country of origin

\begin{tabular}{|l|l|l|}
\hline Country of origin & $\begin{array}{l}\text { Number of issued } \\
\text { declarations (absolute } \\
\text { value) }\end{array}$ & Percentage \\
\hline Ukraine & $1,714,891$ & 93.99 \\
\hline Belarus & 58,046 & 3.18 \\
\hline Moldavia & 31,465 & 1.72 \\
\hline Georgia & 11,126 & 0.61 \\
\hline Russia & 6,150 & 0.34 \\
\hline Armenia & 2,786 & 0.15 \\
\hline
\end{tabular}

Source: own research, based on data provided by the MPiPS (2017).

In view of the above, it can be stated that the research problem of whether immigrant employment or the intention to do so in the foreseeable future affects the perception of foreign workers and the perceived necessity to hire them is limited in an implicit extent to Ukrainians.

As already indicated, surveys point to a relatively positive attitude towards immigrants. In 2017, the most popular nations were Czechs (59\% declared), Slovaks and Italians (57\%), followed by Americans and Hungarians (54\%) (CBOS, 2017). In general, Poles like Western nations more (Włoch, 2013). The list of most unpopular nations in Poland in 2017 includes Arabs (59\% antipathy declared), Roma (50\%) and Turks (42\%). The exact distribution of attitudes towards nationals which most often apply for work permits and for which employers issue a declaration of employment are presented in Table 3. Unfortunately, CBOS does not collect data on all of the above-mentioned nations. 
Table 3. Distribution of positive attitude towards selected nations (2017) (\%)

\begin{tabular}{|l|l|l|l|l|l|}
\hline Nations & Sympathy & Indifference & Reluctance & Hard to say & Average $^{*}$ \\
\hline Ukrainians & 36 & 26 & 32 & 6 & 0,05 \\
\hline Belarusians & 37 & 28 & 23 & 12 & 0,33 \\
\hline Russians & 31 & 25 & 42 & 10 & $-0,23$ \\
\hline
\end{tabular}

Note: ${ }^{*}$ The average was calculated on a scale from -3 (max. reluctance) to 3 (max. positive attitude) Source: CBOS (2017).

As emphasised, the attitudes towards Ukrainians are highly polarised and the respondents declared positive attitude only slightly more often than antipathy (CBOS, 2017).

It is important to note that the attitudes towards immigrants change over time. This may result from the fact that when people start to interact with each other and their knowledge increases the stereotypes lose on strength (Bilewicz, 2006) and the positive image of the particular nation may improve. The change of the declared positive attitude towards Ukrainians is presented in Figure 1. 
Figure 1. Change of declared positive attitude and reluctance toward Ukrainians from 1993 to 2017



Sympathy $\rightleftharpoons$ Reluctance

Source: own research based on CBOS (2017).

Especially in recent years the number of issued work permits and employer declarations of intention to entrust work to a Ukrainian has rapidly grown, which may have influenced the change in attitudes towards Ukrainians. However, as already mentioned, the attitudes are highly polarised as the positive attitude and reluctance are on a similar level in recent years.

The attitude towards immigrants depends on many factors, which include, among others, the size of the immigrant population (Semyonov, Raijman, \& Gorodzeisky, 2006), the country's political climate (Semyonov, Raijman, \& Gorodzeisky, 2008) or the media coverage of immigration-related news (Schlueter \& Davidov, 2013). Studies also suggest that contact with immigrants can mitigate negative prejudice (Semyonov \& Glikman, 2009).

Due to the change in the number of economic immigrants in recent years, especially from Ukraine, as well as the change in attitudes towards them, we decided to analyse how the intent to employ an immigrant (the independent variable) affects the employers' attitudes towards an employee's country of 
origin. International research has emphasised the role of economic self-interest in explaining anti-immigration attitudes (Fetzer, 2000). However, most studies focused on how the presence of immigrants on the labour market shapes attitudes towards immigration (Dustmann \& Preston, 2007). Nonetheless, in some research, focusing on theories of economic self-interest, researchers analysed whether people's material self-interest influences their attitudes towards immigration (Hayes \& Dowds, 2006). Some researchers even suggest that the economic interest may be the main reason for the opposition to immigration in Europe and Israel (Raijman, Semyonov, \& Schmidt, 2003) as well the United States (Espenshade \& Hempstead, 1996). As determined by Hayes \& Dowds (2006), also in the United Kingdom people with higher economic status expressed generally more pro-immigrant attitudes. As determined by Turner \& Cross (2015) in a Europe-wide analysis, the economic factor is the most important one, when explaining shifts in attitudes towards immigration. Assuming that organisations willing to employ immigrants do it due to their expected profit (economic self-interest) we adopted the following hypothesis:

$\mathrm{H} 1$ : The intention to employ an immigrant affects the attitude towards an employee's country of origin.

Furthermore, we decided to specify the hypothesis by adding additional hypothesis. Thus we decided to analyse whether the intention to employ an immigrant (the independent variable) affects the employers' perception of the immigrant in comparison to native workers. In relation to this issue, we adopted the following hypothesis:

$\mathrm{H} 2$ : The intention to employ an immigrant affects the employers' perception of the immigrant in comparison to indigenous workers.

Furthermore, we decided to analyse whether the current intention to employ an immigrant (the independent variable) affects the perception of problems with recruiting native workers with the required qualifications as a reason for limiting the company's development opportunities, which could lead them to employing an immigrant. We adopted the following hypothesis: 
H3: The intention to employ an immigrant affects the employers' perception of problems with recruiting native workers with the required qualifications as a reason for limiting the company's development opportunities, which could lead them employ an immigrant.

Finally, we decided to analyse whether this issue affects the general recognition of the necessity of reaching for foreign employees in the coming years. In relation to this issue, we adopted the following hypothesis:

H4: The intention to employ an immigrant affects the employers' general recognition of the necessity of reaching for foreign employees in the coming years.

This hypothesis is relevant, as the research points to the tendency that the predicted immigration affects attitudes towards immigrants (Christensen, Arnesen, \& Midtbo, 2019).

\section{Research design and methodology}

This paper discusses the results of the survey conducted among 263 entrepreneurs from the Opolskie Voivodship. As already indicated, the choice of the Opolskie Voivodship was purposeful as it has become a kind of a 'laboratory' for the study of migration processes. The analysis is based on 263 structured questionnaires with employers selected from the members of the Opole Chamber of Commerce, Klub 150, participants of the international research project pursued by the Opole University of Technology and the University of Opole, as well as those featured in the database of the Opole Voivodship Office as entities that obtained work permits for immigrants. Respondents were contacted in several ways. First, a CAWI (Computer-Assisted Web Interview) research has been conducted. However, the response rate was very low and less than 5 per cent of the group participated in the CAWI survey. Therefore, contacting respondents by e-mail was found to be ineffective. The second method used in the study was PAPI (Paper \& Pen Personal Interview). It is worth noting that not all enterprises agreed to participate in the PAPI study. On average, about one third of all participants refused to talk to the interviewer in 
order to complete the questionnaire. This shows that studies in the business community constitute a challenge. Finally, 263 employers were included in the study - managers, firm owners, directors or supervisors responsible for the human resources management policy in the particular organisation. The organisations represented a variety of sectors: construction (26.6\%), services (25\%), metal industry (11.8\%), food industry (10.7\%), furniture industry, transportation and logistics (4.9\%), wood and paper industry (4.7\%), agriculture (3.8\%), medical services and rehabilitation (2.7\%), chemical industry (1.9\%), fuel and energy industry and tourism (1.5\%). In accordance with the dual labour market theory (Piore, 1979), 19\% of the interviewed organisations employed immigrants in the so-called white-collar jobs, representing the primary labour market segment and $81 \%$ organisations employed immigrants in the blue-collar jobs, representing the secondary labour market. Among the 263 interviewed organisations, $42.97 \%$ were micro-enterprises (excluding the so called one-person-businesses), $33.46 \%$ were small enterprises, $17.11 \%$ were medium enterprises and $6.46 \%$ were large enterprises.

We developed the questionnaire based on an analysis of the existing literature. However, the questions included in the research tool were results of an operationalisation conducted for the purpose of this research. Due to the fact that the questionnaire was built using the nominal and ordinal scale, for most of the questions the quantitative nature of the presented answer choices imposed the choice of tools for the analysis of quantitative variables. We thus chose the $\mathrm{V}$ Cramer contingency measure.

Firstly, the respondents were asked whether they employ or are willing to employ an immigrant. Due to the low number of organisations that employed immigrants at the moment of the study, the organisations declaring the employment and willingness to employ immigrants were considered as a single group in opposition to those not willing to hire foreign workforce. The structure of the sample, based on the declared willingness to employ foreign workforce, is presented in Table 4. 
Table 4. Sample structure based on the declared willingness to employ immigrants

\begin{tabular}{|l|l|l|}
\hline $\begin{array}{l}\text { Employers willing to hire } \\
\text { an immigrant }\end{array}$ & $\begin{array}{l}\text { Employers not willing to } \\
\text { hire an immigrant }\end{array}$ & Total \\
\hline 222 & 41 & 263 \\
\hline $84.41 \%$ & $15.59 \%$ & $100 \%$ \\
\hline
\end{tabular}

Source: own research.

The above declaration was then used as an explanatory variable in the study. Subsequently, the respondents were asked whether a immigrants' country of origin would be (or in case of organisations already employing immigrants "was") an issue. Then, the respondents were asked about their opinions on immigrants in comparison to native employees. The employers were also asked which of the employees, in their opinion, are better and why. The question was a multiple-choice question. Then, the respondents were asked about their perception of problems with recruiting native workers with the required qualifications as a reason for limiting the company's development opportunities, which could lead them to employing an immigrant. Finally, we asked the respondents about their opinion on a possible future need to employ immigrants, including possible reasons of such a necessity.

\section{Research results}

The first analysed issue was the impact of the intention to hire an immigrant on the attitude towards the country of origin of the actual or potential employee. The results are presented in Table 5. 
Table 5. Impact of the declared intention to employ immigrants on the attitude towards the immigrants' county of origin

\begin{tabular}{|l|l|l|l|l|}
\hline & $\chi 2$ & $d f$ & $p$-value & $V$ \\
\hline $\begin{array}{l}\text { Attitude towards the immigrants } \\
\text { country of origin }\end{array}$ & 192.6701 & 7 & 0.0000 & 0.8592 \\
\hline
\end{tabular}

Source: own research.

The results show a strong and statistically-relevant correlation between the analysed variables. In most cases, respondents willing to hire an immigrant declared that the immigrant's country of origin does not play any role. In total, over $52 \%$ of all respondents declared that the country of origin does not play a role, $24 \%$ declared their readiness to employ immigrant from East European countries, 6.5\% declared their readiness to employ an immigrant, but only from one of the EU countries.

Next, we analysed the impact of the intention to hire an immigrant on the employers' perception of the immigrant in comparison to native workers. The results are presented in Table 6.

Table 6. Impact of the declared intention to employ immigrants on the employers' perception of the immigrants in comparison to native workers

\begin{tabular}{|l|l|l|l|l|}
\hline & $\chi 2$ & $d f$ & $p$-value & $V$ \\
\hline $\begin{array}{l}\text { Employers' perception of the immi- } \\
\text { grant in regards to indigenous workers. }\end{array}$ & 43.2920 & 26 & 0.0180 & 0.4088 \\
\hline
\end{tabular}

Source: own research.

The results show a moderate, statistically-relevant correlation between the analysed variables. In most cases, employees willing to hire an immigrant assessed immigrants as better workers than natives. As for the reason, they stated that immigrants are more available and willing to work overtime (22.1\%), have lower wage expectations (17.4\%) and they care more about 
their jobs in general (12\%). Respondents who assessed immigrants as worse employees emphasised that immigrants need more supervision (10.1\%). The respondents also pointed to lower commitment of foreign workers (9.2\%) and a longer process of professional adaptation (5\%). Only 7.8\% assessed foreign workers as the same as Polish workers.

The next analysed issue was the impact of the intention to hire an immigrant on the employers' perception of the problems with recruiting native workers with the required qualifications as a reason for limiting the company's development opportunities, which could lead them to employing an immigrant. The results are presented in Table 7.

Table 7. Impact of the declared intention to hire immigrants on the employers' perception of the problems with recruiting native workers with the required qualifications as a reason for limiting the company's development opportunities

\begin{tabular}{|l|l|l|l|l|}
\hline & $x 2$ & $d f$ & p-value & $V$ \\
\hline $\begin{array}{l}\text { Employers' perception of problems } \\
\text { with recruiting native workers with } \\
\text { the required qualifications as a reason } \\
\text { for limiting the company's develop- } \\
\text { ment opportunities }\end{array}$ & 17.8001 & 3 & 0.0005 & 0.2602 \\
\hline
\end{tabular}

Source: own research.

A total of 33.08\% employers declared problems with recruiting native workers with the required qualifications as a reason for limiting the company's development opportunities. However, 33.08\% stated the opposite. A total of $33.46 \%$ admitted that, despite this not being an issue for them for now considering the dropping number of work-age population, this can become a problem in the near future. One respondent stated that problems with recruiting native workers with the required qualifications are not a reason for limiting the company's development opportunities, but hiring people with too low or no qualifications indeed is. 
Finally, we analysed the impact of the intention to hire an immigrant on the employers' general recognition of the necessity to reach for foreign employees in the coming years. The results are presented in Table 8.

Table 7. Impact of the declared intention to employ immigrants on the employers' general recognition of the necessity of reaching for foreign employees in the coming years

\begin{tabular}{|c|c|c|c|c|}
\hline & $x^{2}$ & $d f$ & p-value & V \\
\hline $\begin{array}{l}\text { Employers' general recognition of the } \\
\text { necessity of reaching for foreign em- } \\
\text { ployees in the coming years }\end{array}$ & 26.4561 & 15 & 0.0335 & 0.3172 \\
\hline
\end{tabular}

Source: own research.

The results show a statistically relevant, however relatively weak, correlation between the analysed variables.

Almost half of the respondents (48.29\%) declared that they think that Poland will have to reach for foreign workforce, especially in seasonal works and physical work, while $19.39 \%$ stated that Poland will have to reach for foreign workforce, especially in elderly care services. Only 5.32\% think that it will soon be necessary to reach for immigrants in high skilled jobs, where specific qualifications are required, and only 3.04\% stated that they recognize the necessity in areas in which the Polish youth does not want to educate in. Only $12.17 \%$ declared that they do not think that Poland will have to reach for foreign workforce in the coming years.

\section{Conclusion and Discussion}

The presented study was designed to determine whether the fact of employing immigrants or the intention to do so in the foreseeable future determines the perception of foreign workers as well as the perceived necessity to 
hire them. The study has shown that statistically relevant correlations exist between the analysed variables. The correlation between the willingness to hire an immigrant and the attitude of the employee towards the country of origin is still very strong. In general, an employer willing to employ an immigrant does not have any prejudice as to the potential employee's country of origin. However, most employers pointed towards Eastern Europe as the direction of arrival of the potential employees, which may result from the fact that currently this region, i.e. Ukraine, is the dominant source of foreign workforce in Poland. This is also consistent with the findings by Dustman \& Preston (2007) who found that the opposition towards further immigration increases with ethnic and cultural distance and thus the respondents pointed towards cultural and ethnic similar countries and the source of potential employees. In regards to the second association, also a statistically-relevant, however moderate correlation was identified. The willingness to employ an immigrant thus affects the perception of the immigrant in comparison to native workers to a certain degree. There are probably other factors affecting the dependent variable, which were not taken into account in this study. It is however not surprising that employers willing to employ an immigrant perceive him or her as equally good or better than a native employee, especially considering the dominant motives for hiring employees determined, among others, by the lack of native workers willing to perform the job or the lower costs of employing an immigrant (Hamid, Singh, Yusof, \& Abdullah, 2011). Especially the first motive can predominantly shape the willingness to employ immigrants in the conducted research, as most of the interviewed organisations represented the secondary labour market. These findings fit the economic self-interest theory. If the organization is forced to employ immigrants, due to the lack of native workforce it will act in its economic self-interest, which will affect the perception of immigrant workforce.

The third analysed hypothesis concerned the impact of the intention to employ an immigrant and the perception of problems with recruiting native workers with the required qualifications as a reason for limiting the 
company's development opportunities, which in effect could lead them to employing an immigrant. The relations between the variables turned out to be statistically-relevant, yet the correlation was small. This results from the fact that most of the employers did not perceive the problem as a burning issue at this time, but recognised that it can become one in the future. Finally, the relation between the intent to employ an immigrant and the employers' general recognition of the necessity of reaching for foreign employees in the coming years was analysed and showed a moderate, but statically-relevant correlation.

The conducted research is not free of limitation. Firstly, due to the exploratory nature of the study and therefore a qualitative nature of most of the questions asked in the survey, the possibilities to conduct a more complex statistically analysis were limited. However, as already indicated, the study was of an exploratory nature. To our best knowledge, the issue in question has not yet been a subject of analysis, which is why we found it important to conduct preliminary research first. The exploratory nature of the study as well as the structure of the sample do not allow to make generalizations as the study is not representative to the entire population of Polish employers, they may however suggest some tendencies which would require further analysis.

Due to the fact that the conducted research was preliminary, further research on this topic is required. We are currently conducting qualitative in-depth-interviews with employers hiring foreign workforce to gain in-depth knowledge about the issue in question. A study on a nationwide sample would also be beneficial. Although, as already mentioned, the Opolskie Voivodship is a laboratory for migrational studies and it would be important to broaden the analysis to a nationwide sample. Also a cross-national study would be interesting, as it can provide information about the impact of economic and cultural factors on the willingness to employ immigrants.

The paper has also research and practical implications. By understanding how the economic self-interest influences the perception of immigrants an understanding may be gained on what may facilitate the integration of 
immigrants in Poland and in the Polish labour market. The paper shows an existing willingness to employ foreign workforce, which correlates with an openness towards the country of origin. This can be an important conclusion for decision-makers to further facilitate access to the Polish labour market for a wider group of immigrants, especially since a significant group of employees recognises the upcoming issue of workforce shortages and the necessity to reach for foreign employees in order to stay competitive. Also in view of the above, theoretical implications emerge. It becomes visible that further studies, not only on the impact of willingness to employ immigrants on attitudes of employers, but also in general on the issue of employing foreign workforce are required. Especially due to the lasting very high homogeneity of the Polish society and ambiguous attitudes of Poles towards the nations, which dominate the economic migrants' influx, further research is required. Furthermore, considering the finding of Dustman \& Preston (2007) who found that the opposition towards further immigration increases with ethnic and cultural distance, similar research in regards to other immigrant groups should be conducted. The relatively high willingness to employ immigrants can also be an indicator of the need of a more broader introduction and implementation of diversity management, which is still not a very popular and widespread approach among Polish organisations (Maj \& Walkowiak, 2015). Also considering that also the history of inward immigration may be affecting attitudes towards migration, especially in times of economic crises, as shown on the example of Greece, Spain and Portugal (Turner \& Cross, 2015) further research should include additional mediating variables.

The findings of the research in relation to the trends in attitudes towards studies on immigrants are optimistic as to the future development in the diversification of the Polish workforce and the economic growth and also the increase in the organisations' performance. 


\section{References}

Aleksynska, M., \& Tritah, A. (2015). The heterogeneity of immigrants, host countries' income and productivity: a channel accounting approach. Economic Inquiry, 53(1), 150-172. doi:10.1111/ecin.12141.

Ang, S., van Dyne, L., \& Begley, T. M. (2003). The employment relationships of foreign workers versus local employees: a field study of organizational ustice, job satisfaction, performance, and OCB. Journal of Organizational Behavior, 24, 561-583. doi:10.1002/ job.202.

Arltova, M., \& Langhamrova, J. (2010). Migration and Ageing of the population of the Czech Republic and the EU countries. Prague Economic Papers, 19(1), 54-73. doi:10.18267/j.pep.364.

Bilewicz, M. (2006). Kiedy kontakt osłabia uprzedzenia? Kategoryzacje społeczne i temporalne jako warunki skuteczności kontaktu międzygrupowego. Psychologia Społeczna, 1(2), 164-175.

Bloch, N., \& Gozdziak, E. M. (2010). Od gości do sąsiadów: integracja cudzoziemców spoza Unii Europejskiej w Poznaniu w edukacji, na rynku pracy iw opiece zdrowotnej: praca zbiorowa. Centrum Badań Migracyjnych UAM.

Brzozowski, J., \& Pędziwiatr, K. (2014). Analiza procesu integracji imigrantów w Małopolsce (Analysis of the integration process of immigrants in Małopolska). In Imigranci w Małopolsce. Między integracją, asymilacją, separacją, marginalizacją (Immigrants in Małopolska. Between integration, assimilation, separation, marginalization) (pp. 117-240). Kraków: Akademia Ignatianum in Kraków.

CBOS (2017). Stosunek do innych narodów. Retrieved from Warszawa: http://www. cbos.pl/SPISKOM.POL/2017/K_021_17.PDF. Access: 22.07.2019. 
Constant, A. F. (2014). Do migrants take the jobs of native workers? Retrieved from https://wol.iza.org/uploads/articles/10/pdfs/do-migrants-take-the-jobs-of-nativeworkers.pdf. Access: 22.07.2019.

Christensen, D. A., Arnesen, S., \& Midtbo, T. (2019). Do immigration scenarios influence Norwegians' attitudes towards immigrants? A survey experiment. Tidsskrift for Samfunnsforskning, 60(2), 123-139. doi:10.18261/issn.1504-291X-2019-02-01.

D'Souza, G. C., \& Colarelli, S. M. (2010). Team member selection decisions for virtual versus face-to-face teams. Computers in Human Behavior, 26(4), 630-635. doi:10.1016/j.chb.2009.12.016.

Dietz, B., \& Kaczmarczyk, P. (2008). On the demand side of international labour mobility: The structure of the German labour market as a causal factor of seasonal Polish migration. In: C. Bonifazi, M. Okólski, J. Schoorl, \& P. Simon (Eds.), International Migration in Europe: New Trends and New Methods of Analysis (pp. 37-64). Amsterdam: Amsterdam University Press.

Doeringer, P. B., \& Piore, M. J. (1985). Internal labor markets and manpower analysis: ME Sharpe.

Douglas, S., Massey, J. A., Graeme Hugo, A. K., \& Taylor, J. E. (2009). Worlds in motion. Understanding International Migration at the End of the Millennium. Oxford: Clarendon Press.

Dovidio, J. F., Gaertner, S. L., Kawakami, K., \& Hodson, G. (2002). Why can't we just get along? Interpersonal biases and interracial distrust. Cultural Diversity and Ethnic Minority Psychology, 8(2), 88-102. doi:10.1037//1099-9809.8.2.88.

Dustmann, C., \& Preston, I. P. (2007). Racial and economic factors in attitudes to immigration. BE Journal of Economic Analysis \& Policy, 7(1). doi:10.2202/1935-1682.1655 
Dvorakova, Z., \& Langhamrova, J. (2013). Population ageing and its Human Resources Management Consequences. 7th International Days of Statistics and Economics, 365-374.

Espenshade, T. J., \& Hempstead, K. (1996). Contemporary American attitudes toward US immigration. International Migration Review, 30(2), 535-570. doi:10.2307/2547393.

Fetzer, J. S. (2000). Economic self-interest or cultural marginality? Anti-immigration sentiment and nativist political movements in France, Germany and the USA. Journal of Ethnic and Migration Studies, 26(1), 5-23. doi:10.1080/136918300115615.

Foged, M., \& Peri, G. (2016). Immigrants' Effect on Native Workers: New Analysis on Longitudinal Data. American Economic Journal-Applied Economics, 8(2), 1-34. doi:10.1257/app.20150114.

Gheasi, M., Nijkamp, P., \& Rietveld, P. (2017). Wage gaps between native and migrant graduates of higher education institutions in the Netherlands. Letters in Spatial and Resource Science, Relation to other nations, 10(3), 277-296. doi:10.1007/s12076016-0174-6.

Gmaj, K. (2005). Imigranci na polskim rynku pracy w świetle opinii pracodawców. Raporty i Analizy, 3(5), 1-35.

Golinowska, S. (2004). Popyt na pracę cudzoziemców: Polska i sąsiedzi. Instytut Pracy i Spraw Socjalnych.

Grabowska-Lusińska, I., \& Żylicz, A. (2008). Czy Polska gospodarka potrzebuje cudzoziemców? Ośrodek Badań nad Migracjami WNE UW. 
Grzymała-Kazłowska, A. (2008). Między jednością a wielością: integracja odmiennych grup i kategorii imigrantów w Polsce (Between unity and plurality: integration of different groups and categories of immigrants in Poland). Ośrodek Badań nad Migracjami WNE UW.

GUS (2014). Baza danych Eurostatu ze Spisu 2011. Wybrane tablice dotyczące przynależności narodowo-etnicznej, języka i wyznania - NSP 2011. Retrieved from: http://stat.gov.pl/spisy-powszechne/nsp-2011/nsp-2011-wyniki/wybrane-tablice-dotyczace-przynaleznosci-narodowo-etnicznej-jezyka-i-wyznania-nsp-2011,8,1.html. Access: 22.07.2019.

Górny, A. (2007). Położenie i zachowania imigrantów na mazowieckim rynku pracy. In: A. Górny, A. Grzymała-Kazłowska, E. Kępińska, A. Fihel \& A. Piekut (Eds.) Od zbiorowości do społeczności: rola migrantów osiedleńczych w tworzeniu się społeczności imigranckich w Polsce (pp. 69-86). Center of Migration Research, Centre of Migration. Research Faculty of Economic Sciences Warsaw University.

Hamid, A. R. A., Singh, B., Yusof, A. M., \& Abdullah, N. A. M. (2011). The Employment of Foreign Workers at Construction Sites. Paper presented at the 2nd International Conference on Construction and Project Management (ICCPM 2011). Singapore.

Hayes, B. C., \& Dowds, L. (2006). Social contact, cultural marginality or economic self-interest? Attitudes towards immigrants in Northern Ireland. Journal of Ethnic and Migration Studies, 32(3), 455-476. doi:10.1080/13691830600554890.

Heffner, K., \& Solga, B. (2013). Features of a migration region - an analysis using the example of the Opolskie Voivodship. Bulletin of Geography. Socio-economic Series, 20(20), pp. 48-58. doi:10.2478/bog-2013-0010.

Hunt, J. (2011). Which Immigrants Are Most Innovative and Entrepreneurial? Distinctions by Entry Visa. Journal of Labor Economics, 29(3), 417-457. doi:10.1086/659409. 
Jehn, K. A., Northcraft, G. B., \& Neale, M. A. (1999). Why differences make a difference: A field study of diversity, conflict, and performance in workgroups. Administrative Science Quarterly, 44(4), 741-763.

Jordaan, J. A. (2018). Foreign workers and productivity in an emerging economy: The case of Malaysia. Review of Development Economics, 22(1), 148-173. doi:10.1111/ rode.12334.

Klaus, W., \& Wencel, K. (2010). Dyskryminacja cudzoziemców w Polsce w latach 20082010. In W. Klaus (Ed.), Sąsiedzi czy intruzi? O dyskryminacji cudzoziemców w Polsce (pp. 61-133). Warszawa: Instytut Spraw Publicznych i Stowarzyszenie Interwencji Prawnej.

Kubiciel-Lodzińska, S. (2017). The Determinants of Employment of Foreigners in Polish Companies (Based on Empirical Findings). Proceedings of the International Multidisciplinary Scientific Conference on Social Sciences \& Arts SGEM, 453-460. doi:10.5593/sgemsocial2017/41.

Kubiciel-Lodzińska, S., \& Ruszczak, B. (2016). The determinants of student migration to Poland based on the Opolskie Voivodeship study. International Migration, 54(5), 162-174. doi:10.1111/imig.12257.

Kukulak-Dolata, I., \& Sobocka-Szczapa, H. (2013). Synteza wyników badania mikropodmiotów w Polsce. Warszawa: IPiSS.

Lau, D. C., \& Murnighan, J. K. (1998). Demographic diversity and faultlines: The compositional dynamics of organizational groups. Academy of Management Review, 23(2), 325-340.

Maj, J., \& Walkowiak, Ł. (2015). Diversity Management in Polish Organizations. Proceedings in ARSA-Advanced Research in Scientific Areas, 79-82, doi: 10.18638/ arsa.2015.4.1.750. 
Markusen, J. R., \& Trofimenko, N. (2009). Teaching locals new tricks: Foreign experts as a channel of knowledge transfers. Journal of Development Economics, 88(1), 120-131. doi:10.1016/j.jdeveco.2008.02.002.

Mor Barak, M. E. (2010). Managing Diversity: Toward a Globally Inclusive Workplace. SAGE Publications.

MPiPS (2017). Cudzoziemcy pracujący w Polsce - statystyki (Foreigners working in Poland - statistics). Retrieved from https://www.mpips.gov.pl/analizy-i-raporty/ cudzoziemcy-pracujacy-w-polsce-statystyki/. Access 21.03.2018.

Ottaviano, G. I. P., \& Peri, G. (2006). The economic value of cultural diversity: Evidence from US cities. Journal of Economic Geography, 6(1), 9-44. doi:10.1093/jeg/lbi002.

Parrotta, P., Pozzoli, D., \& Pytlikova, M. (2014). Labor diversity and firm productivity. European Economic Review, 66, 144-179. doi:10.1016/j.euroecorev.2013.12.002.

Peri, G. (2016). Immigrants, Productivity, and Labor Markets. Journal of Economic Perspectives, 30(4), 3-30. doi:10.1257/jep.30.4.3.

Piore, M. J. (1979). Birds of passage: migrant labor and industrial societies. Cambridge University Press.

Raijman, R., Semyonov, M., \& Schmidt, P. (2003). Do Foreigners Deserve Rights? Determinants of Public Views Towards Foreigners in Germany and Israel. European Sociological Review, 19(4), 379-392+i. doi:10.1093/esr/19.4.379.

Reyneri, E. (2004). Immigrants in a segmented and often undeclared labour market. Journal of Modern Italian Studies, 9(1), 71-93. doi:10.1080/1354571042000179191. 
Schlueter, E., \& Davidov, E. (2013). Contextual Sources of Perceived Group Threat: Negative Immigration-Related News Reports, Immigrant Group Size and their Interaction, Spain 1996-2007. European Sociological Review, 29(2), 179-191. doi:10.1093/ esr/jcr054.

Schweiger, D. M., Sandberg, W. R., \& Ragan, J. W. (1986). Group Approaches for Improving Strategic Decision Making: A Comparative Analysis of Dialectical Inquiry, Devil's Advocacy, and Consensus. The Academy of Management Journal, 29(1), 51-71.

Semyonov, M., \& Glikman, A. (2009). Ethnic Residential Segregation, Social Contacts, and Anti-Minority Attitudes in European Societies. European Sociological Review, 25(6), 693-708. doi:10.1093/esr/jen075.

Semyonov, M., Raijman, R., \& Gorodzeisky, A. (2006). The rise of anti-foreigner sentiment in European societies, 1988-2000. American Sociological Review, 71(3), 426-449. doi:10.1177/000312240607100304.

Semyonov, M., Raijman, R., \& Gorodzeisky, A. (2008). Foreigners' Impact on European Societies Public Views and Perceptions in a Cross-National Comparative Perspective. International Journal of Comparative Sociology, 49(1), 5-29. doi:10.1177/0020715207088585.

Solga, B., \& Kubiciel-Lodzinska, S. (2017). Poland: immigration instead of emigration. Transformation of the mobility model. In K. Soliman (Ed.), Vision 2020: Sustainable Economic development, Innovation Management, and Global Growth (pp. 797-810). Madrid: International Business Information Management Association.

Turner, T., \& Cross, C. (2015). Do attitudes to immigrants change in hard times? Ireland in European context. European Societies, 17(3), 372-395. doi:10.1080/14616 696.2015 .1035298 
Van de Kaa, D. J. (1999). Europe and its population: the long view. In European Populations (pp. 1-49). Springer.

Włoch, R. (2013). Poland: Multiculturalism in the Making? In R. Taras (Ed.), Challenging Multiculturalism: European Models of Diversity (pp. 257-278). Edinburgh: Edinburgh University Press. 